Abstracta Iranicacta Iranica

Revue bibliographique pour le domaine irano-aryen

Volume 40-41 | 2019

Comptes rendus des publications de 2017-2018

\title{
Ulrich Hübner, Herbert Niehr (Hg.). Sprachen in Palästina im 2. und 1. Jahrtausend v. Chr
}

\section{Astrid Nunn}

\section{(2) OpenEdition}

1 Journals

\section{Édition électronique}

URL : http://journals.openedition.org/abstractairanica/48326

DOI : 10.4000/abstractairanica.48326

ISBN : 1961-960X

ISSN : 1961-960X

Éditeur :

CNRS (UMR 7528 Mondes iraniens et indiens), Éditions de l'IFRI

Référence électronique

Astrid Nunn, «Ulrich Hübner, Herbert Niehr (Hg.). Sprachen in Palästina im 2. und 1. Jahrtausend v. Chr », Abstracta Iranica [En ligne], Volume 40-41 | 2019, document 29, mis en ligne le 15 juillet 2019, consulté le 17 avril 2021. URL : http://journals.openedition.org/abstractairanica/48326 ; DOI : https://doi.org/ 10.4000/abstractairanica.48326

Ce document a été généré automatiquement le 17 avril 2021

Tous droits réservés 


\title{
Ulrich Hübner, Herbert Niehr (Hg.). Sprachen in Palästina im 2. und 1. Jahrtausend v. Chr
}

\author{
Astrid Nunn
}

\section{RÉFÉRENCE}

Ulrich Hübner, Herbert Niehr (Hg.). Sprachen in Palästina im 2. und 1. Jahrtausend v. Chr. Kolloquium des Deutschen Vereins zur Erforschung Palästinas, 02.-04.11.2012, Mainz. Wiesbaden: Harrassowitz Verlag, 2017, VI+396p. (Abhandlungen des Deutschen Palästina-Vereins 43)

1 La "Palestine" englobait Cananéens, Israelites, Judéens, Phéniciens, Araméens, Philistins, Arabes, Ammonites, Moabites et Edomites. S'ajoutaient aux multiples langues de ces populations celles de leurs souverains égyptiens, assyriens, babyloniens, achéménides et enfin grecs. En conséquence, rien n'est plus logique que la Palestine n'ait jamais représenté une entité linguistique. Cette excellente monographie présente les langues parlées et écrites dans cette région du Bronze Moyen II à la fin du I ${ }^{\text {er }}$ millénaire. Quelques contributions seulement abordent directement la Palestine achéménide (cf. dans ce numéro les cr de Dusek, Xella, Schmitt). 


\section{AUTEURS}

\section{ASTRID NUNN}

Université de Munich 